Article

\title{
Psychoeducation for Attention Deficit/Hyperactivity Disorder: What, How and Who Shall We Inform?
}

\author{
Clarissa Tochetto de Oliveira* \\ Orcid.org/0000-0002-2624-8843 \\ Ana Cristina Garcia Dias \\ Orcid.org/0000-0003-2312-3911
}

Universidade Federal do Rio Grande do Sul, Porto Alegre, RS, Brasil

\begin{abstract}
The aim of this study was to review scientific publications about Attention Deficit/Hyperactivity Disorder (ADHD) psychoeducation. A systematic review of literature was performed in eight national and international databases (Scielo Brazil, Index Psi, Pepsic, Lilacs, ScienceDirect, PsycINFO, Medline, and Scopus) using the combination of ADHD and psychoeducation as keywords. In total, 504 studies were found, although only 29 met the inclusion criteria. Afterwards, the information was organized into categories: the concept of psychoeducation, target population, focus of ADHD psychoeducation, variables related to ADHD psychoeducation, and the characteristics of intervention on ADHD psychoeducation. Results show that not all studies present the concept of psychoeducation adopted by the authors. In general, psychoeducation has focused on the relatives of people with ADHD and carried out as group sessions, lectures, and manuals. ADHD psychoeducation contributes to a better understanding of the disorder, treatment adherence, quality of life, and decreased symptoms of ADHD.
\end{abstract}

Keywords: Attention deficit disorder with hyperactivity, psychoeducation, literature review.

\section{Psicoeducação do Transtorno do Déficit de Atenção/Hiperatividade: O Que, Como e Para Quem Informar?}

\section{Resumo}

O objetivo deste estudo foi caracterizar as publicações científicas sobre psicoeducação do Transtorno do Déficit de Atenção/Hiperatividade (TDAH). Foi realizada uma revisão sistemática da literatura em oito bases de dados nacionais e internacionais. Utilizou-se a combinação das palavras-chave TDAH e psicoeducação. No total, foram encontrados 504 trabalhos completos, mas apenas 29 preencheram os critérios de inclusão para análise na íntegra. As informações foram organizadas nas categorias: conceito de psicoeducação, público-alvo, foco da psicoeducação do TDAH, variáveis relacionadas à psicoeducação do TDAH, e características das intervenções em psicoeducação do TDAH. Verificou-se que nem todas as

\footnotetext{
Mailing address: Rua Ramiro Barcelos, 2600, Bairro Rio Branco, Porto Alegre, RS, Brazil 90035-003. Phone: (51) 3316-5066. E-mail: clarissa.tochetto@gmail.com

Agradecemos ao Conselho Nacional de Desenvolvimento Científico e Tecnológico (CNPq) e Fundação de Amparo à Pesquisa do Estado do Rio Grande do Sul (FAPERGS) pelo financiamento e à Karen Rech Braun pela colaboração como juíza.
} 
publicações apresentam claramente o conceito de psicoeducação utilizado. Em geral, a psicoeducação tem sido destinada a familiares de pessoas com TDAH, e conduzida em formato de sessões grupais, palestras e manuais. A psicoeducação do TDAH contribui para maior conhecimento sobre o transtorno, adesão ao tratamento, qualidade de vida e menor intensidade dos sintomas do TDAH.

Palavras-chave: Transtorno da falta de atenção com hiperatividade, psicoeducação, revisão de literatura.

\section{La Psicoeducación del Trastorno por Déficit de Atención/Hiperactividad: Qué, Cómo ya Quién Informar?}

\section{Resumen}

El objetivo de este estudio fue caracterizar las publicaciones científicas sobre la psicoeducación del Trastorno por Déficit de Atención/Hiperactividad (TDAH). Se realizó una revisión sistemática de la literatura en ocho bases de datos nacionales e internacionales con la combinación de palabras clave psicoeducación y TDAH. En total, fueran encontrados 504 estudios, pero sólo 29 cumplieron los criterios de inclusión para el análisis en su totalidad. La información se organiza en categorías: concepto de la psicoeducación, la audiencia, el enfoque de la psicoeducación del TDAH, las variables relacionadas con la psicoeducación del TDAH, y características de las intervenciones en la psicoeducación del TDAH. Se ha encontrado que no todas las publicaciones muestran claramente el concepto de psicoeducación utilizado. En general, la psicoeducación se ha diseñado para familiares de personas con TDAH, y llevado a cabo en el formato de sesiones de grupo, conferencias y manuales. La psicoeducación del TDAH contribuye a un mayor conocimiento sobre el trastorno, la adherencia al tratamiento, calidad de vida y menor intensidad de los síntomas del TDAH.

Palabras clave: Trastorno por Déficit de Atención/Hiperactividad, psicoeducación, revisión de literatura.

Attention Deficit/Hyperactivity Disorder (ADHD) is characterized by a persistent pattern of inattention, hyperactivity, and impulsivity (American Psychiatric Association [APA], 2013). These symptoms are of neurobiological origin and are due to the inability to sustain attention, inhibit impulsive reactions and think before acting (Barkley, Fischer, Smallish, \& Fletcher, 2002). As a result, people diagnosed with this disorder tend to present academic, professional, family, and social impairments. Additionally, ADHD is considered a chronic disease. Symptoms begin before the age of 12 (APA, 2013), tend to remain throughout life in approximately $70 \%$ of cases (Lara et al., 2009) and change according to the period of individual development. In adulthood, inattention can be manifested by avoiding activities that require attention maintenance, such as watching movies and reading; hyperactivity in the form of internal restlessness or discomfort; and impulsiveness may appear in decisions made without thinking about the consequences (Conners, 2009).

Regardless of the developmental stage, treatment for people with this disorder involves a combination of medication (to minimize the symptoms of inattention, hyperactivity and impulsivity) and the adoption of psychological interventions, such as those proposed by cognitive-behavioral therapy (CBT), which aim to develop strategies to deal with residual symptoms (Mongolia \& Hechtman, 2016; Sprich, Safren, Finkelstein, Remmert, \& Hammerness, 2016). However, nonadherence to treatment may range from $13.2 \%$ to $64.0 \%$ (McCarthy, 2014). Among the factors that concur to nonadherence are the lack of knowledge of ADHD, medication characteristics, and treatment goals (Charach \& Fernandez, 2013). Therefore, providing information about these aspects to patients and their families 
is important for them to seek and maintain adequate treatment.

The use of the term psychoeducation began in the 1980s and referred to the transmission of information about mental disorders to family members and psychotic patients. In the 1990s, psychoeducation focused on other groups with different mental disorders (such as bipolar disorder, post-traumatic stress disorder, etc.; Bonsack, Rexhaj, \& Favrod, 2015). Currently, this term refers both to the provision of relevant information to patients about the disorder (diagnosis, etiology, functioning), treatment and prognosis, as well as to the clarification of doubts and corrections of distorted information. Psychoeducation aims to broaden the knowledge of the patient/ family member about their problem (Menezes \& Souza, 2012; Swadi, Bobier, Price, \& Craig, 2010) in order to increase the understanding of their condition and help in decision making based on reliable information, as well as to promote treatment adherence (Bégin, Bluteau, Arseneault, \& Pronovost, 2012; Bonsack et al., 2015, Swaminath, 2009). Didactic manner and appropriate language should always be considered for the target population, which may consist of patients, family members, educators, and health professionals. The transmission of such knowledge can be done in different forms, individually or in groups, and include lectures, conversation wheels, manuals, videos or bibliotherapy (Bai, Wang, Yang, \& Niu, 2015). Psychoeducation presents various benefits, such as increased knowledge about the disorder, motivation for change, participation in treatment, satisfaction with psychological treatment, greater adherence to it, and relapse reduction (Burlingame, Ridge, Matasuno, Hwang, \& Ernshaw, 2006; Knapp, 2004; Nussey, Pistrang, \& Murphy, 2013).

Psychoeducation programs are more effective in reducing the symptoms of ADHD when compared to isolated drug treatments, which indicates psychoeducation as a valid additional approach for treating ADHD (Ferrin et al., 2016). In addition, identifying information relevant to each case, tailoring the information transfer according to the characteristics of the target popu- lation, and verifying if the message was in fact understood may contribute to the patient's engagement in treatment (Burlingame et al., 2006; Knapp, 2004). Therefore, the objective of this study was to characterize scientific publications on the psychoeducation of ADHD. In particular, the objective was to identify the concept of psychoeducation used by researchers, to whom psychoeducation is intended, as well as the focus of psychoeducation and the related variables and interventions in psychoeducation for ADHD.

\section{Method}

A systematic review of the literature on psychoeducation of ADHD was carried out. The search was performed on the Scielo Brazil, Index Psi, Pepsic, Lilacs, ScienceDirect, PsycINFO, Medline, and Scopus databases. These databases were chosen based on their access to the full texts of national (Scielo Brazil, Index Psi and Pepsic) and international publications (Lilacs, ScienceDirect, PsycINFO, Medline and Scopus) in the electronic medium. Combinations between the descriptors ADHD/TDAH or Attention Deficit/Hyperactivity Disorder/Transtorno do Déficit de Atenção/Hiperatividade with psychoeducation/psicoeducação, bibliotherapy/ biblioterapia or psychoeducational intervention/ intervenção psicoeducativa were used in the abstract field. These keywords were chosen based on the purpose of the study.

In total, 504 complete papers were found. Searches in the Brazilian databases identified only three papers using the combined descriptors. Of these, only one was incorporated into the final sample (Mesquita, Porto, Rangé, \& Ventura, 2009), since the other two were duplicates or unavailable. The remaining 501 articles were retrieved from international databases, in which two judges read the abstracts in order to delimit the sample of papers. The inclusion criteria for article participation in the final sample of this study were: (a) to address psychoeducation of ADHD, (b) to be written in Portuguese, English or Spanish, and (c) to be published in scientific journals, meaning books, book chapters, dissertations and theses were not included. In this stage 
of analysis, 475 studies were excluded (Figure 1). The concordance index among judges was $89.65 \%$. Disagreements were solved by access- ing the publications as a whole and re-evaluating them according to the first inclusion criterion.

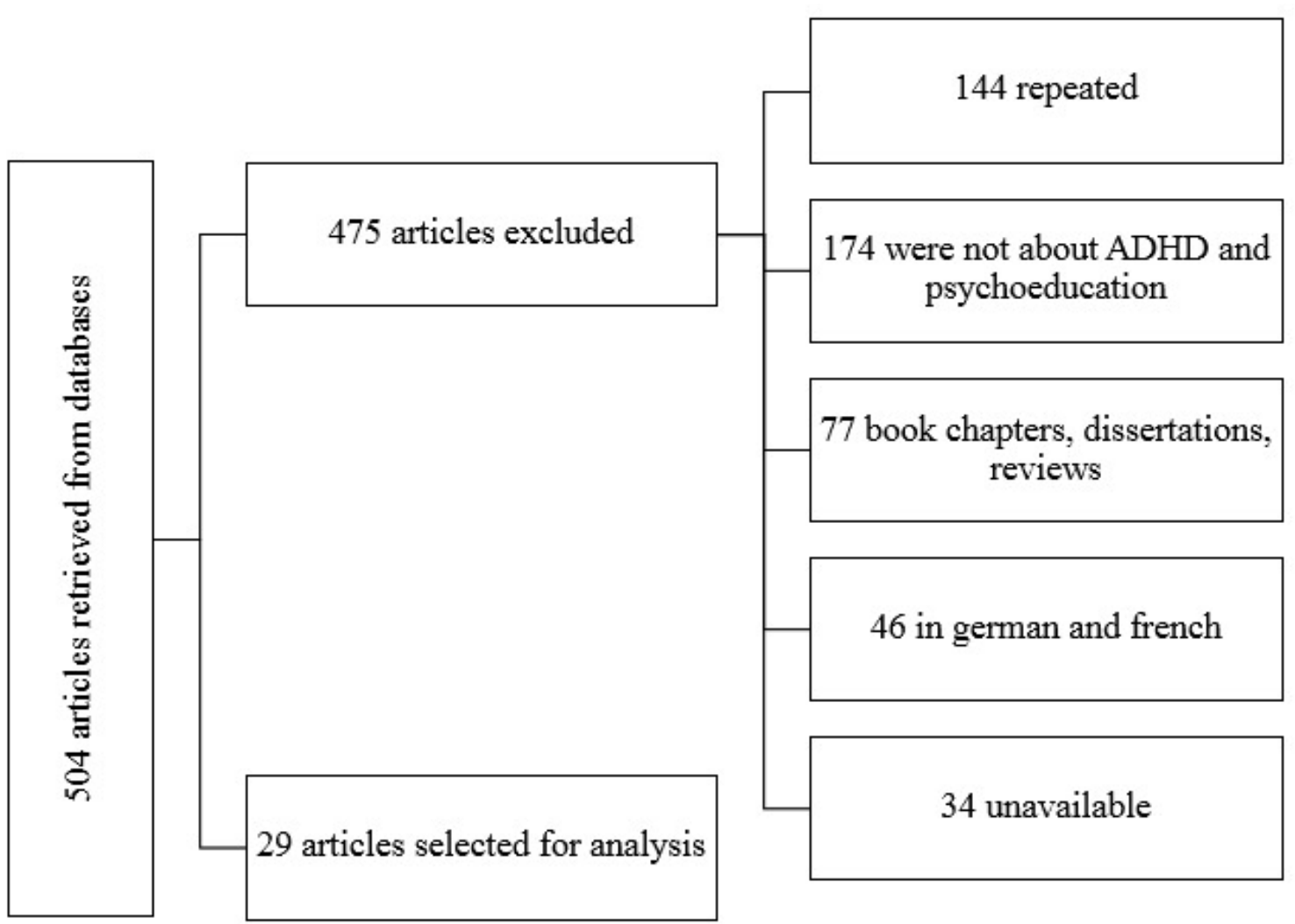

Figure 1. Screening procedures of retrieved articles

The final sample consisted of 29 international publications, which were evaluated in four stages: exploratory, selective, analytical and interpretive reading (Gil, 2006). In the first stage, the papers were read entirely. In the second stage, an in-depth reading of the method, results and conclusion sections was done. The third stage consists of organizing the information in order to identify the main characteristics of psychoeducation (concept, target population, focus and related variables). The fourth and final step groups the information into categories defined a priori, based on the objective of the study:

1. Concept of psychoeducation,

2. Target population,

3. Focus of ADHD psychoeducation,

4. Variables related to psychoeducation of ADHD,

5. Characteristics of interventions in psychoeducation of ADHD.

\section{Results and Discussion}

Overall, 29 international studies were analyzed, in which 14 had experimental designs (Aguiar et al., 2014; Anderson \& Guthery, 2015; Bai et al., 2015; Ferrin et al., 2014; Hirvikoski, Waaler, Lindström, Bölte, \& Jokinen, 2015; Janssen et al., 2014; Kądziela-Olech, 2012; Korzeniowsk \& Ison, 2008; Long, Rickert, \& Ashcraft, 1993; McCarty, Vander Stoep, Violette, \& Myers, 2015; McCleary \& Ridley, 1999; Montoya et al., 2014; Myers, Vander Stoep, Thompson, Zhou, \& Unützer, 2010; Vidal et al., 2013); eight were literature reviews (Asherson, 2012; Hernández \& Gutiérrez, 2014; Hill, 2015; Knouse, Cooper-Vince, Sprich, \& Safren, 2008; Montoya, Colom, \& Ferrin, 2011; Murphy, 2005; Nussey et al., 2013; Young, 1999); four were surveys (Altin, Altin, \& Semerci, 2016; Bussing et al., 2012; Coletti et al., 2012; 
Palacios-Cruz et al., 2013); and three were case studies (Hogue, Bobek, \& Evans, 2014; Levine $\&$ Anshel, 2011; Mesquita et al., 2009). In general, studies with an experimental design and case studies consist of ADHD psychoeducational interventions for family members of children or adolescents with ADHD. Literature reviews presented ADHD psychoeducation for chil- dren, adolescents, adults, family, and school and health professionals. Finally, the survey studies sought to assess the knowledge of adolescents, parents and teachers about ADHD. Information on the concept of psychoeducation adopted by the researchers, target population, psychoeducation focus, and related variables are described in Table 1.

Table 1

Characteristics of ADHD Psychoeducation in this Sample of Articles

\begin{tabular}{lcc}
\hline $\begin{array}{l}\text { Authors } \\
\text { (year) }\end{array}$ & $\begin{array}{c}\text { Target } \\
\text { population }\end{array}$ & $\begin{array}{c}\text { Concept } \\
\text { of psychoeducation }\end{array}$ \\
\hline $\begin{array}{l}\text { Aguiar et al. } \\
(2014)\end{array}$ & $\begin{array}{c}\text { Elementary } \\
\text { School Teachers }\end{array}$ & None \\
$\begin{array}{l}\text { Altin et al. } \\
(2016)\end{array}$ & $\begin{array}{c}\text { Adults with } \\
\text { ADHD }\end{array}$ & $\begin{array}{c}\text { Part of the treatment that helps } \\
\text { the patient and his/her family } \\
\text { to give meaning to symptoms } \\
\text { and obtain awareness about } \\
\text { the disorder and its impacts }\end{array}$
\end{tabular}

$\begin{array}{lc}\begin{array}{l}\text { Anderson \& } \\ \text { Guthery } \\ (2015)\end{array} & \begin{array}{c}\text { Parents of children } \\ \text { with ADHD or }\end{array} \\ \begin{array}{l}\text { Asherson } \\ (2012)\end{array} & \begin{array}{c}\text { Adolescents and } \\ \text { adults with ADHD }\end{array} \\ \begin{array}{l}\text { Bai et al. } \\ (2015)\end{array} & \text { Relatives of } \\ & \text { children (6-16 years } \\ & \text { old) } \\ & \text { with ADHD }\end{array}$

Bussing et al. Adolescents with (2012) high and low risk of developing ADHD

Coletti et al. Parents of children (2012) with ADHD

Ferrin et al. Relatives of (2014)

Relatives of
children/
dolescents with

ADHD
None

None

Specific therapeutic program focusing on didactic communication of information and providing patients and families with coping skills

Health Belief Model (HBM) assesses patient perceptions that can be targets of psychoeducational interventions, including perceptions of disorder seriousness, susceptibility, and benefits of interventions

None

Systematic and didactic approach, adequate for informing patients and their relatives about the disorder and its treatment, facilitating its understanding and personal handling

Psychoeducation Related focus variables

ADHD (symptoms, None
etiology, clinical vignettes, strategies for dealing with the disorder)

None None

Mindfulness

Stress

Medication and

None coping strategies

ADHD (symptoms, causes, lifelong harm), medication (side effects, efficacy and safety), treatment options (efficacy)

Knowledge about ADHD and medication

None

$$
\begin{aligned}
& \text { ADHD knowledge } \\
& \text { of adolescents } \\
& \text { and their parents } \\
& \text { and preferred } \\
& \text { information } \\
& \text { sources }
\end{aligned}
$$

\section{ADHD and medication}

ADHD and behavior strategies to handle symptoms
Decision to initiate medication treatment

ADHD symptoms, psychopathology, quality of life, family stress 


\begin{tabular}{lc}
\hline $\begin{array}{l}\text { Authors } \\
\text { (year) }\end{array}$ & $\begin{array}{c}\text { Target } \\
\text { population }\end{array}$ \\
\hline $\begin{array}{l}\text { Hernández \& } \\
\text { Gutiérrez } \\
(2014)\end{array}$ & $\begin{array}{c}\text { Patients, relatives } \\
\text { and teachers }\end{array}$
\end{tabular}
Hill (2015) Children, parents, schools, and health professionals
Hirvikoski et Adults with al. (2015)

Hogue et al. (2014)

Janssen et al. Parents of children (2014) and adolescents
with ADHD

KądzielaOlech (2012)

Knouse et al. (2008)

Korzeniowsk \& Ison (2008)

Parents of children with ADHD

Adults with ADHD

Parents and teachers of children with ADHD

Levine \& Anshel (2011)
Child (eight years old), mother and teacher

None

Well-established, evidence-based intervention for several psychiatric disorders that aims to empower patients and their significant others with knowledge about the disorder and its treatment

A set of interactive educational interventions that provides structured information about ADHD. This information is packaged in an easy-to-digest format and sets the stage for developing a unique family profile of ADHD symptoms and related behavioral characteristics for each client

None

Information about the disorder and its treatment for patients, family and teachers

None

None

Giving people information about their diagnosis encourages the development of independent problem-solving skills

$\begin{array}{cc}\begin{array}{c}\text { Psychoeducation } \\ \text { focus }\end{array} & \begin{array}{c}\text { Related } \\ \text { variables }\end{array}\end{array}$

Correct distorted
beliefs about
etiology, symptoms,
diagnosis, treatment,
and management
strategies
ADHD (causes, comorbidity, impairments), medication (limitations)

None

DHD in adulthood impairment at work and in relationships, pharmacological and psychological treatment, coping strategies, and services available

\author{
Treatment \\ satisfaction, \\ dropout rate, \\ self-esteem, \\ knowledge about \\ ADHD, quality \\ of life
}

ADHD symptoms, School performance, course of the self-efficacy, disorder, effects self-regulation on multiple domains of academic skills, of functioning collaboration (family, school, between parents peers), and school and individual differences associated with ADHD in adolescents

None
ADHD symptoms, mental health, quality of life, treatment adherence
ADHD (etiology, Severity of ADHD diagnostic) and symptoms treatment.

$$
\text { ADHD None }
$$

\section{ADHD, school difficulties, strategies to cope with symptoms}

Diagnostic, worries about peer rejection, and motivation to participate in behavioral interventions
ADHD symptoms, problematic behaviors, educative strategies,
symptoms of depression (sadness and low self-esteem)




\begin{tabular}{|c|c|c|}
\hline $\begin{array}{l}\text { Authors } \\
\text { (year) }\end{array}$ & $\begin{array}{c}\text { Target } \\
\text { population }\end{array}$ & $\begin{array}{c}\text { Concept } \\
\text { of psychoeducation }\end{array}$ \\
\hline $\begin{array}{l}\text { Long et al. } \\
\text { (1993) }\end{array}$ & $\begin{array}{c}\text { Relatives } \\
\text { of children } \\
\text { (6-11 years old) } \\
\text { with ADHD }\end{array}$ & $\begin{array}{l}\text { Bibliotherapy: reading as a } \\
\text { therapeutic technique }\end{array}$ \\
\hline $\begin{array}{l}\text { McCarty et al. } \\
(2015)\end{array}$ & $\begin{array}{l}\text { Caregivers } \\
\text { of children } \\
\text { with ADHD }\end{array}$ & $\begin{array}{l}\text { Pictures, graphs, and a brief text } \\
\text { to help caregivers and children } \\
\text { understand that ADHD and its } \\
\text { related behaviors are "brain-based } \\
\text { and the goals of treatment }\end{array}$ \\
\hline $\begin{array}{l}\text { McCleary \& } \\
\text { Ridley (1999) }\end{array}$ & $\begin{array}{c}\text { Parents of } \\
\text { adolescents with } \\
\text { ADHD }\end{array}$ & $\begin{array}{l}\text { Improve parents' abilities } \\
\text { to cope with and manage } \\
\text { theproblems associated with } \\
\text { adolescent ADHD by: } \\
\text { providing information about } \\
\text { ADHD, enhancing parenting } \\
\text { skills (negotiation and conflict } \\
\text { management skills), } \\
\text { and supporting parents' sense } \\
\text { of competence }\end{array}$ \\
\hline
\end{tabular}

Mesquita

Adults with ADHD

et al. (2009)

Montoya

et al. (2011)

Parents and teachers of children and adolescents

with ADHD

$\begin{array}{lc}\text { Montoya } & \text { Parents of children } \\ \text { et al. (2014) } & \text { with ADHD }\end{array}$

Allow patients to recognize his/her symptoms, impairments and coping strategies

A novel treatment paradigm, which includes information about the illness and its treatment, skill development, and patient empowerment besides being considered a well-established evidence-based practice for some severe psychiatric disorder in the adulthood

None

$\begin{gathered}\text { Psychoeducation } \\ \text { focus }\end{gathered}$
Use of social
learning principles
in the management
of children.

ADHD (etiology, neurobiology, comorbidities, treatments, impact on life phases), behavior reinforcement and extinction strategies, and parent abilities to handle symptoms

\section{ADHD and coping strategies}

Related variables
ADHD symptoms, child's behavior, knowledge about behavioral techniques

Caregivers' engagement
ADHD,

cognitive model, pharmacological treatment and comorbidities

ADHD, comorbidities, treatment adherence, relationship with parents, peers and teachers, social skills, quality of life

None

Depression

None

$$
\begin{aligned}
& \text { ADHD (etiology, } \\
& \text { symptoms, } \\
& \text { comorbidities, } \\
& \text { treatment } \\
& \text { diagnostic, treatment, } \\
& \text { prognostic), coping } \\
& \text { strategies, social } \\
& \text { skills, and attention } \\
& \text { problems solution }
\end{aligned}
$$




\begin{tabular}{|c|c|c|c|c|}
\hline $\begin{array}{l}\text { Authors } \\
\text { (year) }\end{array}$ & $\begin{array}{c}\text { Target } \\
\text { population }\end{array}$ & $\begin{array}{c}\text { Concept } \\
\text { of psychoeducation }\end{array}$ & $\begin{array}{c}\text { Psychoeducation } \\
\text { focus }\end{array}$ & $\begin{array}{l}\text { Related } \\
\text { variables }\end{array}$ \\
\hline $\begin{array}{l}\text { Murphy } \\
(2005)\end{array}$ & $\begin{array}{l}\text { Adolescents and } \\
\text { adults with ADHD }\end{array}$ & $\begin{array}{l}\text { A sound knowledge base } \\
\text { can help patients and family } \\
\text { members cope more effectively; } \\
\text { help patients make sense } \\
\text { of what has been impairing them; } \\
\text { and assist them in setting realistic } \\
\text { treatment goals. Explaining the } \\
\text { rationale for making the ADHD } \\
\text { diagnosis and ways in which } \\
\text { the patient meets the DSM-IV } \\
\text { criteria can help demystify } \\
\text { the diagnosis and put it in the } \\
\text { context of each patient's own } \\
\text { unique life experience }\end{array}$ & $\begin{array}{l}\text { ADHD (diagnostic } \\
\text { criteria, effects } \\
\text { on the patient's } \\
\text { life, treatment) }\end{array}$ & None \\
\hline $\begin{array}{l}\text { Myers et al. } \\
(2010)\end{array}$ & $\begin{array}{l}\text { Children (6-12 } \\
\text { years old) }\end{array}$ & None & $\begin{array}{l}\text { ADHD (etiology } \\
\text { and management) }\end{array}$ & $\begin{array}{l}\text { ADHD symptoms, } \\
\text { treatment adherence } \\
\text { and satisfaction }\end{array}$ \\
\hline $\begin{array}{l}\text { Nussey et al. } \\
(2013)\end{array}$ & $\begin{array}{l}\text { Parents, teachers } \\
\text { and peers (children } \\
\text { and adults) }\end{array}$ & None & ADHD and Tourette & None \\
\hline $\begin{array}{l}\text { Palacios-Cruz } \\
\text { et al. (2013) }\end{array}$ & Teachers & None & $\begin{array}{c}\text { Assessment of } \\
\text { teachers' knowledge } \\
\text { about it }\end{array}$ & $\begin{array}{l}\text { ADHD } \\
\text { knowledge } \\
\text { and beliefs }\end{array}$ \\
\hline $\begin{array}{l}\text { Vidal et al. } \\
\text { (2013) }\end{array}$ & Adults with ADHD & $\begin{array}{c}\text { Intervention focused } \\
\text { on improving the patients' } \\
\text { understanding and awareness } \\
\text { of the disorder }\end{array}$ & $\begin{array}{l}\text { ADHD (symptoms, } \\
\text { causes, impairments) } \\
\text { and treatment } \\
\text { (medication), } \\
\text { relaxation and } \\
\text { cognitive model } \\
\text { of ADHD }\end{array}$ & $\begin{array}{l}\text { ADHD symptoms, } \\
\text { depression, } \\
\text { quality of live }\end{array}$ \\
\hline Young (1999) & Adults with ADHD & $\begin{array}{c}\text { Dispelling erroneous beliefs } \\
\text { about the disorder and providing } \\
\text { information about its etiology and } \\
\text { prognosis }\end{array}$ & $\begin{array}{l}\text { ADHD (etiology, } \\
\text { prognostic and } \\
\text { associated factors) }\end{array}$ & $\begin{array}{l}\text { Self-esteem, } \\
\text { treatment } \\
\text { adherence }\end{array}$ \\
\hline
\end{tabular}

\section{Concept of Psychoeducation}

Psychoeducation is a result of the integration of several theories and complementary clinical models, such as cognitive-behavioral theory, learning theory, group practice model, stress modeling and coping strategies, social support model, among others (Lukens \& McFarlane, 2004). For instance, professionals can apply psychoeducation as an isolated cognitive intervention (Bäuml, Froböse, Kraemer, Rentrop, \& Pitschel-Walz, 2006) or as a strategy in CBT to increase the understanding of patient's symptoms and engage her or him in treatment (Knapp, 2004). Therefore, the definition of what researchers understand by psychoeducation is relevant to facilitate the understanding of professionals interested in applying study results to their practice.

Some analyzed articles did not present the concept of psychoeducation adopted by the authors (Aguiar et al., 2014; Anderson \& Guthery, 2015; Asherson, 2012; Coletti et al., 2012; Hill, 2015; Janssen et al., 2014; Knouse et al., 2008; Korzeniowsk \& Ison, 2008; Montoya et al., 2014; Myers et al., 2010; Nussey et al., 2013; Palacios-Cruz et al., 2013). One study (Murphy, 
2005) described the benefits of patients and families in acquiring knowledge about ADHD, how to identify what harms them, and how to develop realistic treatment goals. However, this study did not present a clear definition of psychoeducation.

Other studies defined psychoeducation as a form of interactive intervention between professionals and the patient(s)/family (Bai et al., 2015; Hirvikoski et al., 2015; Hogue et al., 2014; Montoya et al., 2011). Psychoeducational intervention assesses perceptions of the disorder and treatment (Bussing et al., 2012; Young, 1999), and then provides information about ADHD and coping strategies in a systematic and didactic way (Bai et al., 2015; Ferrin, et al., 2014; Hogue et al., 2014; Montoya et al., 2011). Its goal is to help patients and others involved to understand the disorder, its consequences and treatment goals (Altin et al., 2016; Hernández \& Gutiérrez 2014; Kądziela-Olech, 2012; Levine \& Anshel, 2011; McCarty et al., 2015; Mesquita et al., 2009; Vidal et al., 2013; Young, 1999) as well as empower patients (Hirvikoski et al., 2015) and their relatives in dealing with problems associated with the disorder (Levine \& Anshel, 2011; McCleary \& Ridley, 1999; Mesquita et al., 2009). Furthermore, bibliotherapy is an alternative that consists of reading as a therapeutic technique, since self-help manuals can be an effective tool for a variety of problems (Long et al., 1993).

These results reveal the need of clearly defining what the authors understand by psychoeducation and its application as the main intervention or as part of a more comprehensive treatment strategy. Specifying its application in clinical and community settings for various target populations may also be useful for clinicians and researchers (Lukens \& McFarlane, 2004).

\section{Focus of ADHD Psychoeducation}

The objective of psychoeducation is to provide relevant information to the patient or other people interested in a particular subject (Menezes \& Souza, 2012; Swadi et al., 2010). In the sample analyzed, the focus of psychoeducation addressed the disorder itself and treatment op- tions. In particular, the psychoeducation about the disorder itself involved the following aspects: (a) symptoms of the disorder (Aguiar et al., 2014; Bai et al., 2015; Coletti et al., 2012; Hernández \& Gutiérrez 2014; Hirvikoski et al., 2015; Hogue et al., 2014; Kądziela-Olech, 2012; Levine \& Anshel, 2011; Mesquita et al., 2009; Montoya et al., 2014; Murphy, 2005; Nussey et al., 2013; Vidal et al., 2013), (b) causes (Aguiar et al., 2014; Bai et al., 2015; Hernández \& Gutiérrez 2014; Hill, 2015; McCarty et al., 2015; Montoya et al., 2014; Myers et al., 2010; Vidal et al., 2013; Young, 1999), (c) impairments due to the disorder (Bai et al., 2015; Hill, 2015; Hirvikoski et al., 2015; Hogue et al., 2014; Kądziela-Olech, 2012; McCarty et al., 2015; McCleary \& Ridley, 1999; Murphy, 2005; Vidal et al., 2013), and (d) existing comorbidities (Hill, 2015; McCarty et al., 2015; Mesquita et al., 2009; Montoya et al., 2011; Montoya et al., 2014).

Psychoeducation regarding ADHD addressed topics such as medication (Asherson, 2012; Bai et al., 2015; Coletti et al., 2012; Hill, 2015; Hirvikoski et al., 2015; Mesquita et al., 2009; Vidal et al., 2013) and strategies for symptom management (Ferrin et al., 2014; Hernández \& Gutiérrez 2014; Hirvikoski et al., 2015; McCarty et al., 2015; McCleary \& Ridley, 1999; Montoya et al. 2014; Myers et al., 2010). In cases of psychoeducation of relatives of children or adolescents with ADHD, intervention also addressed necessary parenting skills for caregivers to improve their relationship with the child and better manage the symptoms of the disorder (Kądziela-Olech, 2012; Levine \& Anshel, 2011; Long et al. 1993, Montoya et al., 2011, Montoya et al., 2014).

One of the studies analyzed did not address psychoeducation itself, although it investigated the level of knowledge adolescents (with high and low risk for ADHD) and their parents had about the disorder. Participants reported incorrect information about ADHD (such as believing that elevated sugar consumption or misuse of medication could cause it) although they thought they were familiar with it. This highlights the need to increase access to information about ADHD. In addition, it is also possible to 
observe in the paper that adolescents and parents often seek information on the internet, social networks, and television, although only parents search for printed material and health professionals' opinions (Bussing et al., 2012). Another study showed that parents value the attempts of professionals to explain the disorder and use of medication. However, parents varied in their preference concerning the amount of information received and the way information was made available. Some parents preferred detailed information in the form of a pamphlet and/or the internet, while others preferred brief information transmitted orally by health professionals (Coletti et al., 2012). These results indicate sources to access the target population at the time of ADHD psychoeducation.

Another study assessed the knowledge and beliefs of public and private school teachers about ADHD. Most teachers considered ADHD a mental disorder (79.3\%) and reported the psychologist as the competent professional to perform its diagnosis and treatment. On the other hand, less than half (44.1\%) believed that combined therapy is the ideal option and just $14.7 \%$ thought medication was the main component of treatment. Nevertheless, they recognized the effects of treatment on the social and academic functioning of students with ADHD (PalaciosCruz et al., 2013). These results indicate the need to psychoeducate teachers about the etiology of ADHD as well as treatment options and efficacy. After all, teachers interact with students on a daily basis and can assist in the identification and referral of those who may be affected by the disorder.

\section{Target Population}

One of the factors that determine the format of psychoeducation is the target population for which it is intended. In the analyzed sample, psychoeducation was performed for one or more populations. Most studies have developed psychoeducation aimed at family members of children and adolescents with ADHD (Anderson \& Guthery, 2015; Bai et al., 2015; Coletti et al., 2012; Ferrin et al., 2014; Hernández \& Gutiérrez 2014; Hill, 2015; Hogue et al., 2014; Janssen et al., 2014; Kądziela-Olech, 2012; Korzeniowsk \& Ison, 2008; Levine \& Anshel, 2011; Long et al., 1993; McCarty et al., 2015; McCleary \& Ridley, 1999; Montoya et al., 2011; Montoya et al., 2014; Myers et al., 2010; Nussey et al., 2013), or of adults with ADHD (Hirvikoski et al., 2015). One study was conducted with children with ADHD (Levine \& Anshel, 2011), four with adolescents with ADHD (Asherson, 2012; Bussing et al., 2012; Hogue et al., 2014; Murphy, 2005), and eight with adults with ADHD (Altin et al., 2016; Asherson, 2012; Hirvikoski et al., 2015; Knouse et al., 2008; Mesquita et al., 2009; Murphy, 2005; Vidal et al., 2013; Young, 1999). The other studies addressed psychoeducation of ADHD for teachers (Aguiar et al., 2014; Hernández \& Gutiérrez 2014; Hill, 2015; Kądziela-Olech, 2012; Korzeniowsk \& Ison, 2008; Montoya et al., 2011; Nussey et al., 2013; Palacios-Cruz et al., 2013) and basic health professionals (Hill, 2015).

Notably, researchers have a growing concern of whether psychoeducation should be directly delivered to the family members rather than the patients themselves. There are two possible explanations for this point in question. The first justification is that, historically, ADHD has been considered an exclusive disorder of childhood. Thus, the treatment of the child with ADHD depended on the engagement of the parents, which justifies the need to psychoeducate the relatives of children and adolescents with the disorder. Evidence that ADHD interferes with patients' self-esteem (APA, 2013) highlights the need to also adapt psychoeducation for children, adolescents and adults in 2004 (Lukens \& McFarlane, 2004). However, despite being over a decade later, the number of published studies about ADHD psychoeducation targeted at patients is still lower than those intended for their family members. The second possible explanation is that ADHD in adults only began to be studied of late and was just recently been inserted in the Diagnostic and Statistical Manual of Mental Disorders (DSM-5; APA, 2013), which may also justify the modest number of studies on psychoeducation for this population. Despite the gaps identified in the reports of psychoeducation for different publics, 
it is recommended that the general population receive especial attention regarding ADHD psychoeducation, since it can contribute not only to the identification of untreated cases but also increase positive attitudes towards people with ADHD (Nussey et al., 2013).

\section{Variables Related to the $A D H D$ Psychoeducation}

The studies analyzed found that ADHD psychoeducation was related to greater adherence to treatment by patients and relatives, higher levels of stress (Anderson \& Guthery, 2015; Ferrin et al., 2014; Hirvikoski et al., 2015), improved self-esteem (Young, 1999), greater knowledge about the disorder (Aguiar et al., 2014; Bai et al., 2015; Hirvikoski et al., 2015), better quality of life (Ferrin et al., 2014; Hirvikoski et al., 2015; Janssen et al., 2014; Vidal et al., 2013), decreased symptoms of ADHD and other psychopathologies (Ferrin et al., 2014; Janssen et al., 2014; Kądziela-Olech, 2012; Korzeniowsk \& Ison, 2008; Levine \& Anshel, 2011; Long et al., 1993; Mesquita et al., 2009; Myers et al., 2010; Vidal et al., 2013), greater collaboration between caregivers and schools, and higher levels of academic achievement (Hogue et al., 2014).

The variables associated with ADHD psychoeducation in the studies analyzed are in line with the variables used to measure the impact on psychoeducational interventions in general. Evidence on psychoeducation programs in general shows that it seems to be associated with the reduction of symptoms linked to ADHD, anxiety, and depression (regardless of the focus of psychoeducation), in addition to greater adherence and satisfaction with the treatment, greater knowledge, improved self-esteem, coping strategies and quality of life (Lukens \& McFarlane, 2004).

\section{Characteristics of Interventions in ADHD Psychoeducation}

In the analyzed sample, 17 studies presented psychoeducational interventions for people with diagnosis or signs of ADHD. The diagnosis was made by triangulation of data in five surveys (Bai et al., 2015; Ferrin et al., 2014; Hirvikoski et al., 2015; Levine \& Anshel 2011; Montoya et al., 2014). In fact, the diagnosis of ADHD is clinical and requires the collection of information from different sources, such as scales and semi-structured interviews based on the DSM-5 criteria with the patient, collection of information with the individual's relatives, identification of the contexts in which nuclear symptoms are present, as well as the functional impairment associated with them (Mattos et al., 2006). The other studies analyzed based the diagnosis only on diagnostic criteria (Hogue et al., 2014; Kądziela-Olech, 2012; Vidal et al., 2013), scales (McCarty et al., 2015; Mesquita et al., 2009; Vidal et al., 2013), clinical interviews (Janssen et al., 2014; Long et al., 1993; McCleary \& Ridley, 1999; Myers et al., 2010) or trust in prior clinical diagnosis (Korzeniowsk \& Ison, 2008), which can lead to misdiagnosis since ADHD and other disorders share similar symptoms such as mood and anxiety disorders (Searight, Burke, \& Rootnek, 2000).

Most interventions consisted of a set of interactive group sessions (Ferrin et al., 2014; Hirvikoski et al., 2015; Hogue et al., 2014; Korzeniowsk \& Ison, 2008; McCarty et al., 2015; McCleary \& Ridley, 1999; Montoya et al., 2014; Vidal et al., 2013), while others occurred in the form of lectures associated with dealing with the disorder (Aguiar et al., 2014; Bai et al., 2015), bibliotherapy (Anderson \& Guthery, 2015; Long et al., 1993), and individual encounters (Levine \& Anshel, 2011; Mesquita et al., 2009). Only two studies reported who received psychoeducation without describing how it was performed (Janssen et al., 2014; Myers et al., 2010). Another study reported the follow-up of a monthly psychoeducational intervention for parents and teachers of children with ADHD after one and 10 years, although it did not describe how psychoeducation was performed (duration, individual or group, place, team; Kądziela-Olech, 2012).

In all studies, questionnaires and scales were used to assess the outcome variables at least twice (pre and post intervention), except for 
three studies that performed qualitative assessments (Hogue et al., 2014; Korzeniowsk \& Ison, 2008; Levine \& Anshel, 2011). Process measures, such as presence in sessions, dropout rate, and training of facilitators were rarely assessed.
The study of Aguiar et al. (2014) described the training offered to the professional team that conducted the intervention, and the one by Myers et al. (2010) evaluated the presence of the parents in the intervention sessions.

Table 2

Characteristics of ADHD Psychoeducation Interventions

\begin{tabular}{lccc}
\hline $\begin{array}{l}\text { Authors } \\
\text { (year) }\end{array}$ & ADHD & Intervention & Assessment \\
& diagnosis & model &
\end{tabular}

Aguiar et al. None (teachers)

(2014)

\section{Anderson \& \\ Guthery (2015) \\ Children with ADHD or ADHD traits}

Bai et al. (2015)

Ferrin et al. (2014)

Based on DSM-IV, on Barkley's Clinical Diagnostic Interview Scale and on a psychiatrist evaluation

Based on DSM-IV, confirmed
One six-hour session: well-balanced mixture of lectures on ADHD, presentations of clinical vignettes specially constructed for challenging potential misconceptions, followed by a vivid group discussion about ADHD issues (etiology and strategies for managing ADHD at school). Written manual summarizing the content discussed.

Bibliotherapy for parents (Everyday Blessings: The Inner Work of Mindful Parenting) by clinic interview with psychiatry, structured interview (KSADS-PL)

Two 40-minute sessions with a maximum of 10 parents in order to give information about side effects and answer questions.

Lecture and manual for parents based on four components: 1- ADHD information,

2- Treatment-related information outlining pharmaceutical and non-pharmaceutical approaches, 3- Barriers to adherence and coping skills, 4- Parenting skills for ADHD children and adolescents

The manual included forms on which behavior and side effects.

Online community with information about health, communication with other parents and with those responsible for interventions

12 weekly sessions of 90 minutes Sessions 1-9: ADHD, Sessions 10-12: behavioral strategies for ADHD symptoms management and reduction of defiant behavior.
Questionnaire to assess ADHD knowledge (symptoms, etiology, strategies to handle the disorder and treatment)

PSI-4-SF, Evaluation of the Mindful Parenting Education Study, treatment satisfaction to record children's medication-taking for groups (a maximum of 10 relatives) Hand-outs at the end of each session.
Questionnaire about ADHD and medication, questions about medication adherence, TPB model, ADHD Rating

Scale-IV, and program satisfaction

K-SADS-PL, Conners' Parent Rating Scale Revised 27-items version, Strengths and Difficulties Questionnaire, Clinical Global Impression Scale, PSI-SF, EuroQoL Five Dimension Questionnaire, PedsQLTM Family Impact Module 


\begin{tabular}{lccc}
\hline $\begin{array}{l}\text { Authors } \\
\text { (year) }\end{array}$ & ADHD & Intervention & Assessment \\
\hline
\end{tabular}

$\begin{array}{lc}\begin{array}{l}\text { Hirvikoski et al. } \\ (2015)\end{array} & \begin{array}{c}\text { Based on clinic } \\ \text { interview according } \\ \text { to DSM-IV-TR, } \\ \text { WURS, ASRS, } \\ \text { and family } \\ \text { information }\end{array}\end{array}$
Hogue et al. Diagnostic criteria (2014) for ADHD

Janssen et al. (2014)

Kądziela-Olech (2012)

Korzeniowsk \& Ison (2008)

Clinic interview

CID-10 criteria
Previous ADHD diagnosis
PEGASUS: eight sessions (150 min with a 30-minute break) in groups (20-30 people with ADHD and significant others) 1- ADHD in adulthood,

2- Pharmacological and psychological treatment, 3- Lifestyle factors,

4- Structure and strategies in everyday life, 5- Living with ADHD, 6- ADHD in relationships, 7- ADHD at work, 8- Service and support provided by society Method: audiovisual material and group discussion

\section{CASH-AA}

1- ADHD psychoeducation,

2- Motivation and preparation,

3- Behavior change, 4- Collaboration ADHD Style Index and checklists (Problem Scorecards) for ADHD and executive functions psychoeducation

Monthly visits to parents. Modules: 1- Diagnostic, 2- Difficulties kids can face in school with family and peers, 3- Regulation of the child's lifestyle to assure education and consolidation of desirable habits, 4- Reducing the amount of incentives which stimuli and release anxiety, 5-Adjustment of parental expectation regarding children behavior Information for teachers about ADHD nature and how to handle kids in school

Eight weekly sessions for parents. Modules:

1- Information about ADHD, 2- Factors that interfere in ADHD children's behavior, 3- School difficulties and strategies for paying attention, 4- Chips economy, 5- Schedule, 6- Establishing limits, 7- Identifying resources, 8- Problem solving Eight weekly sessions for teachers. Modules:

1- Information about ADHD, 2- ADHD children and educational context, 3- Organization and study habits, 4- ADHD children's attention and motivation, 5- Strategies to handle hyperactivity and impulsivity in classroom, 6- Behavior management and interpersonal relationships, 7- Strategies optimization, 8- Future problems
ADHD 20 questions, QAFM, Rosenberg's Self-Esteem Scale, Adult Attention Deficit/ Hyperactivity Disorder Quality-of-Life

(AAQoL) Scale, Burden Assessment Scale

None

ADHD Rating Scale, Health of the Nation Outcome Scale,

Kidscreen-10, Morisky Adherence Scale

Diagnostic Interview Schedule for Children

Semi structured interview 


\begin{tabular}{lc}
$\begin{array}{l}\text { Authors } \\
\text { (year) }\end{array}$ & $\begin{array}{c}\text { ADHD } \\
\text { diagnosis }\end{array}$ \\
\hline $\begin{array}{l}\text { Levine \& Anshel } \\
(2011)\end{array}$ & $\begin{array}{c}\text { Child observation, } \\
\text { interview with child, } \\
\text { mother and teacher, } \\
\text { National Initiative for } \\
\text { Children's Healthcare } \\
\text { Quality (NICHQ, based } \\
\text { on DSM-IV), Teacher } \\
\text { Rating Scale of the } \\
\text { BASC-II }\end{array}$ \\
&
\end{tabular}

Long et al. (1993) Clinic interview with pediatrician

McCarty et al. (2015)

McCleary \& Ridley (1999)

Mesquita et al. (2009)

Montoya et al. (2014)
Child Behavior

Checklist and

Computerized

Diagnostic Interview

Schedule

for Children

Clinic interview

DSM-IV criteria and ASRS
DSM-IV-TR criteria, ADHD-RS-IV Parent: Inv, Clinical Global Impression-ADHD Severity
Six weekly sessions. Modules: 1- Understanding ADHD and your child, 2- School advocacy for children with ADHD, 3- Praising and ignoring skills, 4- Giving clear instruction and following through, 5- Time out and other consequences, 6- Putting it all together

Ten weekly sessions of $120 \mathrm{~min}$ in groups of 8-24 parents

Modules: problem solving, getting to know your kid - again, planned ignoring, contingency planning, planning ahead, time out - grounding, sibling relationships, school-related problems, and peer relationships.

Twenty weekly sessions of $50 \mathrm{~min}$ focusing on ADHD and depression symptoms reduction.

Techniques: psychoeducation, problem solving, Socratic questioning, cognitive restructure, schedule activities, reminders and alarms, prioritization, time management, and organization

Five weekly sessions of $90 \mathrm{~min}$ in groups of six parents. Modules: 1- Overview of program content and ADHD (etiology, epidemiology, symptomatology, comorbidities, diagnosis, treatment, prognosis),

2- Reinforcement techniques, 3- Techniques oriented to diminish inadequate behavior, 4- Interventions for attention problems, 5- Recap of previous four sessions
Assessment

Classroom observations, interview with the mother and teacher

Conners Parent Rating Scale-Hyperactivity Index (CPRS-HI), Eyberg Child

Behavior Inventory (ECBI), Behavior Rating ProfileTeacher Rating Scale (BRPT),

Knowledge of Behavioral

Principles as Applied to Children (KBPAC)

Child Behavior Checklist,

Computerized Diagnostic Interview Schedule for

Children, IOWA Conners' Rating Scale, Global Assessment of Improvement scale

Sociodemografic questionnaire, Conflict Behavior Questionnaire (CBQ), Issues Checklist, and a specific qualitative questionnaire in the end of the program

BDI, BAI and ASRS

ADHD-RS-IV Parent: Inv, CGI-ADHD-S, WFIRS-P, Treatment satisfaction questionnaire. 


\begin{tabular}{lccc}
\hline $\begin{array}{l}\text { Authors } \\
\text { (year) }\end{array}$ & ADHD & Intervention & Assessment \\
\hline
\end{tabular}

Myers et al. $\begin{gathered}\text { Clinic interview with } \\ \text { pediatrician (based on }\end{gathered}$
$\begin{gathered}\text { PSM-IV) } \\ \text { DStiology and ADHD management }\end{gathered}$

Vidal et al. (2013) DSM-IV criteria, ADHD-RS and CGI-S

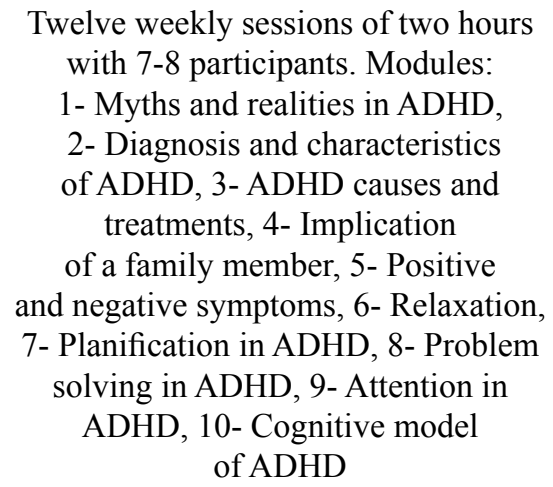

Twelve weekly sessions of two hours with 7-8 participants. Modules: 1- Myths and realities in ADHD, 2- Diagnosis and characteristics of ADHD, 3-ADHD causes and treatments, 4- Implication of a family member, 5- Positive and negative symptoms, 6- Relaxation, 7- Planification in ADHD, 8- Problem solving in ADHD, 9- Attention in ADHD, 10- Cognitive model of ADHD

\author{
Vanderbilt ADHD Rating \\ Scales-Parent (VADPRS) \\ and Teacher (VADTRS) \\ versions, interviews, \\ number of sessions
}

ADHD-RS, CAARS-S, CGI-S, BDI, STAI-S, Quality of Life Enjoyment and Satisfaction

Questionnaire (QLESQ)
Patients usually retain only $50 \%$ of the relevant information transmitted by the professional (Swaminath, 2009), which suggests the need to assess the information acquired by the patients. Only three studies verified whether patients, family members, and teachers in fact understood the information provided in the psychoeducation of ADHD. Bai et al. (2015) used a questionnaire composed of 16 items to assess the knowledge of the parents of children with ADHD. Five items referred to ADHD (nuclear symptoms, causes, losses, if chronic) and 11 to medication (combined treatment, decreased ADHD symptoms, possibility of dependence, side effects). After intervention, participants in the experimental group demonstrated significantly greater knowledge than the control group and increased tendency to adhere to treatments (Bai et al., 2015). Hirvikoski et al. (2015) also assessed the knowledge of participants through a questionnaire. The ADHD 20 Questions consists of 20 items about the beginning of ADHD, possibility of contagion, symptoms, possible impairments, comorbidities, etc. (Bramham et al., 2009). The intervention resulted in greater knowledge of the disorder, psychological wellbeing and quality of the relationship between the adults with ADHD and family members
(Hirvikoski et al., 2015). Aguiar et al. (2014) assessed the knowledge of primary school teachers about ADHD through an instrument built by the researchers themselves based on items in the literature. As a result, they found a reduction in the level of incorrect beliefs about ADHD (Aguiar et al., 2014). The use of instruments such as these can help identify distorted information to be addressed during psychoeducation, as well as serve as a way to assess the effectiveness of psychoeducation for the target population.

\section{Final Considerations}

This study described the characteristics of psychoeducation for ADHD reported in national and international publications. Upon analyzing 29 studies that met inclusion criteria, it is possible to conclude that not all publications clearly present the concept of psychoeducation used, which may confuse readers given the theoretically diverse nature of the construct. The target public of psychoeducational interventions, in most studies, were relatives of people with ADHD. In general, psychoeducation about ADHD seems to contribute to greater knowledge of the disorder, greater adherence to treatment, lower intensity of symptoms, and higher quality 
of life. However, few studies have assessed how much information provided in psychoeducation was in fact retained by the target population.

However, several limitations that may interfere in the interpretation of the presented results should be considered. The literature review was performed with a combination of only five descriptors and in just two languages, thus other articles on the same subject may not have been identified and analyzed. Therefore, results refer only to the sample of articles selected for analysis in this study.

The main contribution of this systematic review was to provide an overview of national and international production on psychoeducation about ADHD available in eight databases, which enabled the identification of aspects that increased the attention of researchers. Notably, no reports of psychoeducation targeted at higher education teachers and health professionals were identified, which points to an exciting field of study aimed at developing psychoeducational interventions about the disorder and its treatment for this public. Additionally, it was possible to observe that the content that must be transmitted in psychoeducation about ADHD is already known, and professionals can invest in further means of contribution (internet, social networks, manuals) in order to reach teenagers and parents.

\section{References}

Aguiar, A. P., Kieling, R. R., Costa, A. C., Chardosim, N., Dorneles, B. V., Almeida, M. R., ...Rohde, L. A. (2014). Increasing teachers' knowledge about ADHD and learning disorders: An investigation on the role of a psychoeducational intervention. Journal of Attention Disorders, 18(8), 691-698. doi:10.1177/1087054712453171

Altin, M., Altin, G. E., \& Semerci, B. (2016). An online survey of Turkish psychiatrists' attitudes about and experiences of adult attention deficit hyperactivity disorder in clinical practice. $\mathrm{Neu}$ ropsychiatric Disease and Treatment, 12, 24552461. doi:10.2147/NDT.S110720

Anderson, S. B., \& Guthery, A. M. (2015). Mindfulness-based psychoeducation for parents of children with Attention-Deficit/Hyperactivity Disorder: An applied clinical project. Journal of Child and Adolescent Psychiatric Nursing, 28(1), 43-49. doi:10.1111/jcap.12103

American Psychiatric Association. (2013). Diagnostic and statistical manual of mental disorders ( $5^{\text {th }}$ ed.). Arlington, VA: Author.

Asherson, P. (2012). ADHD across the lifespan. Medicine, 40(11), 623-627. doi:http://dx.doi. org/10.1016/j.mpmed.2012.08.007

Bai, G. N., Wang, Y. F., Yang, L., \& Niu, W. Y. (2015). Effectiveness of a focused, brief psychoeducation program for parents of ADHD children: improvement of medication adherence and symptoms. Neuropsychiatric Disease and Treatment, 11, 2721-2735. doi:10.2147/NDT.S88625

Barkley, R. A., Fischer, M., Smallish, L., \& Fletcher, K. (2002). The persistence of attention-deficit/ hyperactivity disorder into young adulthood as a function of reporting source and definition of disorder. Journal of Abnormal Psychology, 111(2), 279-89. doi:http://dx.doi.org/10.1037/0021843X.111.2.279

Bäuml, J., Froböse, T., Kraemer, S., Rentrop, M., \& Pitschel-Walz, G. (2006). Psychoeducation: A basic psychotherapeutic intervention for patients with schizophrenia and their families. Schizophrenia Bulletin, 32(1), 51-59. doi:10.1093/ schbul/sbl017

Bégin, J. Y., Bluteau, J., Arseneault, C., \& Pronovost, J. (2012). Psychoeducation in Quebec: Past to Present. Ricerche di Pedagogia e Didattica. Journal of Theories and Research in Education, 7(1), 1-16. doi:10.6092/issn.1970-2221/2681

Bonsack, C., Rexhaj, S., \& Favrod, J. (2015). Psychoéducation: définition, historique, intérêt et limites. Annales Médico-psychologiques, 173(1), 79-84. doi:10.1016/j.amp.2014.12.001

Bramham, J., Young, S., Bickerdike, A., Spain, D., McCartan, D., \& Xenitidis, K. (2009). Evaluation of group cognitive behavioral therapy for adults with ADHD. Journal of Attention Disorders, 12(5), 434-441. doi:10.1177/1087054708314596

Burlingame, G., Ridge, N., Matasuno, J., Hwang, A., \& Ernshaw, D. (2006). Educational needs of inpatients with severe and persistent mental illnesses. Journal of Psychosocial Nursing, 44(1), $39-43$.

Bussing, R., Zima, B. T., Mason, D. M., Meyer, J. M., White, K., \& Garvan, C. W. (2012). ADHD 
knowledge, perceptions, and information sources: Perspectives from a community sample of adolescents and their parents. Journal of Adolescent Health, 51(6), 593-600. doi:10.1016/j. jadohealth.2012.03.004

Charach, A., \& Fernandez, R. (2013). Enhancing ADHD medication adherence: Challenges and opportunities. Current Psychiatry Reports, 15(7), 1-8. doi:10.1007/s11920-013-0371-6

Coletti, D. J., Pappadopulos, E., Katsiotas, N. J., Berest, A., Jensen, P. S., \& Kafantaris, V. (2012). Parent perspectives on the decision to initiate medication treatment of attention-deficit/hyperactivity disorder. Journal of Child and Adolescent Psychopharmacology, 22(3), 226-237. doi:10.1089/cap.2011.0090

Conners, C. K. (2009). Diagnóstico e avaliação do TDAH. In C. K. Conners, Transtorno de déficit de Atenção/hiperatividade: As mais recentes estratégias de avaliação e tratamento. Porto Alegre, RS: Artmed.

Ferrin, M., Moreno-Granados, J. M., Salcedo-Marin, M. D., Ruiz-Veguilla, M., Perez-Ayala, V., \& Taylor, E. (2014). Evaluation of a psychoeducation programme for parents of children and adolescents with ADHD: Immediate and long-term effects using a blind randomized controlled trial. European Child \& Adolescent Psychiatry, 23(8), 637-647. doi:10.1007/s00787-013-0494-7

Ferrin, M., Perez-Ayala, V., El-Abd, S., Lax-Pericall, T., Jacobs, B., Bilbow, A., \& Taylor, E. (2016). A randomized controlled trial evaluating the efficacy of a psychoeducation program for families of children and adolescents with ADHD in the United Kingdom: Results after a 6-month follow-up. Journal of Attention Disorders, 1-12. doi:10.1177/1087054715626509

Gil, A. C. (2006). Métodos e técnicas de pesquisa social. São Paulo, SP: Atlas.

Hernández, P. R., \& Gutiérrez, I. C. (2014). Plan de tratamiento multimodal del TDAH. Tratamiento psicoeducativo. Pediatría Integral, 18(9), 624633.

Hill, P. (2015). Attention-deficit hyperactivity disorder in children and adolescents: Assessment and treatment. BJPsych Advances, 21(1), 23-30. doi:10.1192/apt.bp.114.013953

Hirvikoski, T., Waaler, E., Lindström, T., Bölte, S., \& Jokinen, J. (2015). Cognitive behavior therapybased psychoeducational groups for adults with
ADHD and their significant others (PEGASUS): An open clinical feasibility trial. ADHD Attention Deficit and Hyperactivity Disorders, 7(1), 89-99. doi:10.1007/s12402-014-0141-2

Hogue, A., Bobek, M., \& Evans, S. W. (2014). Changing Academic Support in the home for adolescents with Attention-Deficit/Hyperactivity Disorder: A family-based clinical protocol for improving school performance. Cognitive and Behavioral Practice, 23, 14-30. doi:10.1016/j. cbpra.2014.07.002

Janssen, M., Wensing, M., van der Gaag, R. J., Cornelissen, I., van Deurzen, P., \& Buitelaar, J. (2014). Improving patient care for attention deficit hyperactivity disorder in children by organizational redesign (Tornado program) and enhanced collaboration between psychiatry and general practice: A controlled before and after study. Implementation Science, 9(1), 155-162. doi:10.1186/s13012-014-0155-3

Kądziela-Olech, H. (2012). Attention-deficit/hyperactivity disorder in children - The role of psychoeducation in longitudinal study. Psychiatria i Psychologia Kliniczna, 12(3), 149-156.

Knapp, P. (2004). Terapia Cognitivo-Comportamental na Prática Psiquiátrica. Porto Alegre, RS: Artmed.

Knouse, L. E., Cooper-Vince, C., Sprich, S., \& Safren, S. A. (2008). Recent developments in the psychosocial treatment of adult ADHD. $E x$ pert Review of Neurotherapeutics, 8(10), 15371548. doi:10.1586/14737175.8.10.1537

Korzeniowsk, C., \& Ison, M. (2008). Estrategias psicoeducativas para padres y docentes de niños con TDAH. Revista Argentina de Clínica Psicológica, 18(1), 65-71.

Lara, C., Fayyad, J., De Graaf, R., Kessler, R. C., Aguilar-Gaxiola, S., Angermeyer, M., ...Karam, E. G. (2009). Childhood predictors of adult attention-deficit/hyperactivity disorder: Results from the World Health Organization World Mental Health Survey Initiative. Biological Psychiatry, 65(1), 46-54. doi:10.1016/j.biopsych.2008.10.005

Levine, E. S., \& Anshel, D. J. (2011). "Nothing works!" A case study using cognitive-behavioral interventions to engage parents, educators, and children in the management of attentiondeficit/hyperactivity disorder. Psychology in the Schools, 48(3), 297-306. doi:10.1002/pits.20554 
Long, N., Rickert, V. I., \& Ashcraft, E. W. (1993). Bibliotherapy as an adjunct to stimulant medication in the treatment of attention-deficit hyperactivity disorder. Journal of Pediatric Health Care, 7(2), 82-88. doi:10.1016/08915245(93)90078-V

Lukens, E. P., \& McFarlane, W. R. (2004). Psychoeducation as evidence-based practice: Considerations for practice, research, and policy. Brief Treatment and Crisis Intervention, 4(3), 205. doi:10.1093/brief-treatment/mhh019

Mattos, P., Palmini, A., Salgado, C. A., Segenreich, D., Grevet, E., Oliveira, I. R., ...Lima, P. P. (2006). Painel brasileiro de especialistas sobre o diagnóstico do Transtorno do Déficit de Atenção/Hiperatividade (TDAH) em adultos. Revista de Psiquiatria, 28(1), 50-60.

McCarthy, S. (2014). Pharmacological interventions for ADHD: How do adolescent and adult patient beliefs and attitudes impact treatment adherence? Patient Preference \& Adherence, 8, 1317 1327.

McCarty, C. A., Vander Stoep, A., Violette, H., \& Myers, K. (2015). Interventions developed for psychiatric and behavioral treatment in the Children's ADHD Telemental Health Treatment Study. Journal of Child and Family Studies, 24(6), 1735-1743. doi:10.1007/s10826-0149977-5

McCleary, L., \& Ridley, T. (1999). Parenting adolescents with ADHD: Evaluation of a psychoeducation group. Patient Education and Counseling, 38(1), 3-10. doi:10.1016/S07383991(98)00110-4

Menezes, S. L., \& Souza, M. C. B. (2012). Implicações de um grupo de psicoeducação no cotidiano de portadores de transtorno afetivo bipolar. Revista da Escola de Enfermagem da USP, 46(1), 124131. doi:10.1590/S0080-62342012000100017

Mesquita, C. M. D., Porto, P. R., Rangé, B. P., \& Ventura, P. R. (2009). Terapia cognitivo-comportamental e o TDAH subtipo desatento: Uma área inexplorada. Revista Brasileira de Terapias Cognitivas, 5(1), 35-45. doi:10.5935/18085687.20090004

Mongia, M., \& Hechtman, L. (2016). AttentionDeficit Hyperactivity Disorder across the lifespan: Review of literature on Cognitive Behavior Therapy. Current Developmental Disorders Reports, 3(1), 7-14. doi:10.1007/s40474-0160072-z
Montoya, A., Colom, F., \& Ferrin, M. (2011). Is psychoeducation for parents and teachers of children and adolescents with ADHD efficacious? A systematic literature review. European Psychiatry, 26(3), 166-175. doi:10.1016/j.eurpsy.2010.10.005

Montoya, A., Hervás, A., Fuentes, J., Cardo, E., Polavieja, P., Quintero, J., \& Tannock, R. (2014). Cluster-randomized, controlled 12-month trial to evaluate the effect of a parental psychoeducation program on medication persistence in children with attention-deficit/hyperactivity disorder. Neuropsychiatric Disease and Treatment, 10, 1081-1092. doi:10.2147/NDT.S62487

Murphy, K. (2005). Psychosocial treatments for ADHD in teens and adults: A practice-friendly review. Journal of Clinical Psychology, 61(5), 607-619. doi:10.1002/jclp.20123

Myers, K., Vander Stoep, A., Thompson, K., Zhou, C., \& Unützer, J. (2010). Collaborative care for the treatment of Hispanic children diagnosed with attention-deficit hyperactivity disorder. General Hospital Psychiatry, 32(6), 612-614. doi:10.1016/j.genhosppsych.2010.08.004

Nussey, C., Pistrang, N., \& Murphy, T. (2013). How does psychoeducation help? A review of the effects of providing information about Tourette syndrome and attention-deficit/hyperactivity disorder. Child: Care, Health and Development, 39(5), 617-627. doi:10.1111/cch.12039

Palacios-Cruz, L., de la Peña Olvera, F., Figueroa, G. V., Caballero, A. A., de la Rosa Muñoz, L., Pedroza, ...Flores, R. E. U. (2013). Knowledge and beliefs about attention deficit hyperactivity disorder in teachers from three Latin-American countries. Salud Mental, 36, 257-262.

Searight, H. R., Burke, J. M., \& Rootnek, K. F. (2000). Adult ADHD: Evaluation and treatment in family medicine. American Family Physician, 62(9), 2077-2086.

Sprich, S. E., Safren, S. A., Finkelstein, D., Remmert, J. E., \& Hammerness, P. (2016). A randomized controlled trial of cognitive behavioral therapy for ADHD in medication-treated adolescents. Journal of Child Psychology and Psychiatry. doi:10.1111/jcpp.12549

Swadi, H., Bobier, C., Price, L., \& Craig, B. (2010). Lessons from an audit of psychoeducation at an older adolescent inpatient unit. Australasian Psychiatry, 18(1), 53-58. doi:10.1080/10398560902721580 

Shall We Inform?

Swaminath, G. (2009). Psychoeducation. Indian journal of psychiatry, 51(3), 171-172. doi:10.4103/0019-5545.55082

Vidal, R., Bosch, R., Nogueira, M., Gómez-Barros, N., Valero, S., Palomar, G., ...Ramos-Quiroga, J. A. (2013). Psychoeducation for adults with attention deficit hyperactivity disorder vs. cognitive behavioral group therapy: A randomized controlled pilot study. The Journal of Nervous and Mental Disease, 201(10), 894-900. doi:10.1097/NMD.0b013e3182a5c2c5
Young, S. (1999). Psychological therapy for adults with attention deficit hyperactivity disorder. Counselling Psychology Quarterly, 12(2), 183190. doi:10.1080/09515079908254088

Received: $23 / 09 / 2016$

$1^{\text {st }}$ revision: $23 / 02 / 2017$

Accepted: 28/02/2017

(C) The Author(s), 2018. Open Access. This article is distributed under the terms of the Creative Commons Attribution 4.0 International License (http://creativecommons.org/licenses/by/4.0/), which permits unrestricted use, distribution, and reproduction in any medium, provided you give appropriate credit to the original author(s) and the source, provide a link to the Creative Commons license, and indicate if changes were made. 